the City Corporation, persons having experience in education and knowledge of local educational requirements, and persons to be appointed by the County Council on the nomination of certain suggested educational bodies to be specified in the Bill, among which are the University of London; the City and Guilds of London Institute; the trustees of the City Parochial Foundation; the Association of Technical Institutions; the Society of Arts; the London Chamber of Commerce; and five educational associations; that it is undesirable that there should be any delegation by the authority to such borough committees of powers with regard to education other than elementary.

Ar the third yearly meeting of the Court of Governors of the University of Birmingham, held on February 18 , the principal, Sir Oliver Lodge, referring to the work of the past session, said the University was now recognised by the Board of Education as an inspecting agency for secondary schools in the midland district, and they wanted to inaugurate a new system of examination and inspection, as thereby they could do much good and could help the new education authority not only in the city, but in the neighbouring counties. No doubt some of those present were, or would be, connected with the education authorities in the surrounding districts, and he would say to them, "do not start new training colleges of your own detached from places of learning." At conferences which he had attended at Cambridge and Oxford, at which headmasters and educational workers from all parts of England were present, the opinion was unanimously expressed that teachers should be trained along with men preparing for other professions that they should rub shoulders with professors and teachers not only in their own subjects, but in all subjects. $\mathrm{He}$ should like all teachers to train themselves to some extent both in science and in art. At the British Association, which would meet in September in Lancashire, Sir Norman Lockyer intended to devote a great part of his address to the duty of the State, and of England generally, in undertaking on a totally new and enlarged scale this vital subject to the future of this country. The University ought to take its share in the reorganisation of secondary education. Some secondary authorities were jealous of having university representatives upon them, but they did not want to be there to look after the interests of the university which they represented, but to act as experts, as advisers, not as controllers. If only they could get as professor of education a man of the right type, they might hope to train teachers and influence the youth of England by their means-to train them, he hoped, not in arts alone, nor in science alone, but in originality of thought and fertility of ideas generally.

THE trustees of the Carnegie Trust for the Universities of Scotland met on Monday to receive the annual report and the scheme of endowment of post-graduate study and research drawn up by the executive committee. The Times summary of the report is here abridged. The report stated that there was a natural desire on the part of the universities that under the head of teaching the committee should assign a portion of the annual grants to be used as income. In certain cases of extreme urgency such grants had been given, but they had been limited, both in regard to amount and to the time for which they were payable. It was considered inadvisable to commit the committee to permanent obligations in this direction. Further, the committee considered that in the long run its plan would prove the best for the universities. The scheme adopted, besides making a contribution of $100,000 l$. to the buildings and permanent equipment, and of $20,000 l$. to libraries, would at the close of the period of five years have increased the resources for teaching in the four universities by permanent endowments amounting to $70,500 l .$, while it would at the same time have made during those five years an addition of $\mathrm{rgool}$. a year to the income of two of them. With regard to the endowment of postgraduate study and research, the committee decided that scholarships, fellowships, and grants might with advantage be instituted, but that for many reasons it was not desirable to allot definite sums, or offer separate endowments, to individual universities and institutions. A common scheme had, therefore, been established, the administration of which would be retained in the committee's own hands. It was held that in no other way could the full advantage of this most important branch of the work of the Trust be adequately secured; and the committee regarded it as essential that those who were to profit by the opportunities offered for higher study and research should be the best the universities of Scotland could produce, and their work of the high character which alone was consistent with the intention of the founder. The nominations and applications under this scheme would be referred to an advisory board, consisting of the chairman, the four representatives of the universities and three other members of the Trust. There had been paid by the Trust for the summer session, 1902, the sum of II,976l. 13s. on behalf of 1595 students, representing the fees of $45^{22}$ classes; and for the winter session, 1902-3, the sum of $28,275 \mathrm{l}$. $5 \mathrm{~s}$. On behalf of 2867 students, representing the fees of 8806 classes--in all, for the year to December 3r, 1902, 40,25Il. I8s.

\section{SCIENTIFIC SERIAL}

Journal of Botany, February.-A third contribution of occasional notes on freshwater algæ, which begins in this month's number, is presented by Mr. W. West and Mr. G. S. West. It represents mainly new British forms which have come under observation during the past two years. Several Chantransia and Lemanea forms, originally described by the late Prof. Sirodot, have been obtained in rapid streams in Yorkshire, Cornwall and Westmorland. To the Phæophyceæ are added Phaeococcus paludosus, and a new monotypic genus Phæosphæra. The more important additions to the Chlorophyceæ are Uronema confervicolum, Pseudochaete gracilis (a new genus), Roya cambrica and Debarya desmidioides. The last-mentioned is regarded by the authors as constituting a connecting link between the Desmidiacea and the Zygnemaceæ, since the filaments break up into individual cells, and conjugation occurs only between a pair of such isolated cells.-Continuing his remarks on Calyptopogon mnioides, Mr. E. S. Salmon separates this plant from Streptopogon on account of the papillose areolation and the form of the perichætial leaves, and from Barbula on account of the mitriform calyptra. A complete diagnosis, with an illustrative plate, is appended.-Two short lists of local plants are furnished, one referring to the Bournemouth district, by Mr. E. F. Linton, and the other giving new Bristol records, by Mr. J. W. White, in conjunction with Mr. C. Bucknall and Mr. D. Fry.-A series of "Wayfaring Notes from the Transvaal " is instituted by Dr. R. F. Rand, the first of which discusses botanical features to be observed in the neighbourhood of Johannesburg.-Mr. Garry continues his notes on the drawings for "English Botany."

\section{SOCIETIES AND ACADEMIES. LONDON.}

Royal Society, February I2.- "On the Negative Variation in the Nerves of Warm-blooded Animals." By Dr. N. H. Alcock. Communicated by Dr. A. D. Waller, F.R.S.

The conclusions arrived at are:-

(I) It is possible to examine isolated mammalian and avian nerves under the same conditions as frog's nerves.

(2) There is no essential difference between the nerves of frogs, mammals and birds as regards their negative variation, excitability and reaction to anæsthetics.

(3) There is a marked difference in the extinction point for heat. The negative variation in frog's nerve is abolished at $40^{\circ}-42^{\circ} \mathrm{C}$., in rabbit's nerve at $48^{\circ}-49^{\circ}$, in pigeon's nerve at $53^{\circ}$.

(4) This extinction point corresponds closely with the first coagulation point of the body proteids, where these are known, and thus coagulation is probably the cause of the permanent loss of irritability of the nerve.

(5) The point at which the nerves are paralysed by cold is $-3^{0.5}$ in the frog, $-\mathrm{I}^{\mathrm{O}} 4$ in the hedgehog, $+3^{\circ} .8$ in the rabbit and $+6^{\circ} .9$ in the pigeon.

"Studies in the Morphology of Spore-producing Members. No. V. General Comparison and Conclusion." By Prof. F. O. Bower, F.R.S., Regius Professor of Botany in the University of Glasgow.

$$
\text { NO. I 739, vOL. 67] }
$$


Geological Society, February 4.-Prof. Challes Lapworth, F.R.S., president, in the chair.-The granite and greisen of Cligga Head (West Cornwall), by Mr. J. B. Scrivenor. The small granite-mass between St. Agnes and Perranporth is a remnant of a larger mass which has been partly denuded and partly hidden by a fault; "bedding " is well developed. The granite bordering the bedding-planes has been altered into greisen. Each greisenband contains a quartz-vein, marking the original fissure along which metasomatism took place; the veins contain tourmaline, cassiterite, wolfram, mispickel and chalcopyrite. Two main reactions appear to have taken place in the formation of the greisen : the felspars affording topaz, muscovite and secondary quartz; the biotite brown tourmaline, magnetite and secondary quartz. The greisen is an example of Prof. Vogt's "pneumatolytic" action in thoroughly acid rocks.--Notes on the geology of Patagonia, by $\mathrm{Mr}$. J. B. Scrivenor. The sedimentary strata consist of Tertiary, Cretaceous and Jurassic formations, which, with the exception of the Jurassic, yield varied faunas, both vertebrate and invertebrate. Except in the north, where intrusions of an acid type have disturbed the sediments, the southerly dip is so gentle as only to be appreciable where sections can be followed for some distance. Mr. Hatcher considers that an unconformity separates the Magellanian and Guaranitic Series, also the Cretaceous and Jurassic. Very little is known of the igneous rocks. Apart from those of the Cordillera, there are vast plateaux of basalt and intrusions of quartz-porphyry. The specimens of igneous rocks collected from the moraines of the Cordillera comprise biotitegranite, hornblende-granite, quartz-mica-diorite, gabbro, hornblende-picrite, quartz-porphyry, rhyolite, obsidian, ophitic olivine-dolerites, olivine-basalts and acid tuffs. The basaltflows cover an enormous area. They slope gently towards the Atlantic, and are cut off from the Cordillera by a longitutlinal depression. All that can be said of their age is that they are older than the transverse depressions of the Cordillera, and older than the glaciation of the eastern slopes of that chain. The 'Téhuelche Pebble-Bed, which covers nearly the whole of Patagonia, has been ascribed to marine action by some authors, by others to glacial action. A third suggestion is the agency of big rivers. The drainagesystem includes several eastward-flowing rivers and numerous lakes, some of which occupy transverse valleys cutting through the Cordillera.-On a fossiliferous band at the top of the Lower Greensand, near Leighton Buzzard (Bedfordshire), by Mr. G. W. Lamplugh and Mr. J. F. Walker. This paper describes a newly-discovered fossiliferous band at the top of the Lower Greensand, overlain by the Gault, in the sand-pits at Shenley Hill, near Leighton Buzzard, in Bedfordshire. The fossils of this band present a different facies from that of any other previously-known fossiliferous horizon of the Lower Greensand, and show closer affinities with the fauna of the Upper Greensand than have hitherto been recognised in any deposit below the Gault. The fossiliferous bed is marked off from the underlying unfossiliferous "silver-sands," but more from the overlying Gault. Stratigraphically it forms part of the Lower Greensand, and cannot be considered to belong to the Gault. The fossils constitute the newest Lower Cretaceous fauna as yet recognised in England.

Royal Meteorological Society, February 18.-Captain D. Wilson-Barker, president, in the chair.-Mr. E. Mawley presented his report on the phenological observations for 1902. In all parts of the British Isles, the phenological year ending November 30 , 1902, was for the most part cold and sunless. Rain fell at unusually frequent intervals, so that, although the total quantity proved deficient, there at no time occurred any period of drought. Wild plants were everywhere behind their mean dates in coming into flower, but the departures from the average were, as a rule, slight, until about the middle of May. After that time, until the end of the flowering season, the dates of blossoming were later than in any other year since the present series of records was instituted in $189 \mathrm{I}$. The swallow, cuckoo and nightingale were a few days earlier than usual in making their appearance. The most remarkable feature as regards the weather and its effect on vegetation was the way in which it favoured the growth of all the farm crops, except potatoes and hops. For it is seldom in the same year that the yields of wheat, barley, oats, beans, peas, turnips, mangolds and grass are alike abundant, even in a single district, much less in all parts of the kingdom, as was the case in 1902 . On the other hand all the fruit crops were more or less deficient, with the exception of strawberries, which yielded well, but were like most other fruits, lacking in flavour.

\section{CAMBridge.}

Philosophical Society, January 19.-Mr. Seward, vicepresident, in the chair.- On the invariant factors of a determinant, by the president (Dr. Baker).-On the variation with wave-length of the double refraction in strained glass (second paper), by Mr. L. N. G. Filon.-On the alimentary canal of the mosquito, by Mr. A. E. Shipley. The paper dealt with the alimentary canal of Anopheles maculipennis, Meig., special attention being paid to the mechanism by which "biting" is effected and by which the food is pumped up into the pharynx. Three food reservoirs were described. The alimentary canal, the salivary glands and the Malpighian tubules were described in detail.-A second memoir on integral functions, by Mr. E. W. Barnes. In this paper the author continues certain researches on the asymptotic expansions of integral functions which were published in the Philosophical Transactions of the Royal Society, Series A, vol. cxcix. pp. 4II--500 (1902). Asymptotic expansions are obtained for the standard functions of double sequence, and an attempt is made to classify Taylor's series by means of the asymptotic expansion of the inverse of the $m$ th root of the $m$ th coefficient.-On the theory of shadows. by Mr. H. M. Macdonald.

\section{Dublin.}

Royal Dublin Society, January 20.-Prof. W. F. Barrett, F.R.S., in the chair.-Prof. J. Joly, F.R.S., gave a further account of his preliminary experiments on the conservation of mass which he had presented at the meeting of December 16, 1902.-A paper was read by Dr. W. E. Adeney on the ultra-violet spark spectrum of ruthenium. The first instalment of wave-length determinations in spark spectra from the large Rowland spectrometer in the Royal University, Dublin, is given in this communication, reproductions of photographs from which have already been published in the Scientific Transactions of the Royal Dublin Society, vol. vii., Igor. I46I lines have been measured between the two extreme limits of wave-lengths 2263 and 4560 . Kayser has given 1613 lines as occurring in the arc spectrum between the same limits of wave-length. About 800 lines are common to both forms of the spectrum. Very few in either list are due to impurities. Exner and Haschel have measured $225^{\circ}$ lines between the same limits of wave-length; some 1330 of these occur in the author's photographs.

Literary and Philosophical Society, January $20-\mathrm{Mr}$. Charles Bailey, president, in the chair.-Mr. Thomas Thorp gave an account of some researches he had made on the production of metallic surfaces having the properties of Japanese "magic" mirrors. A passage was read from "Light, Visible and Invisible," by Prof. Silvanus Thompson, pp. $5^{\mathrm{I}-5^{2}}$, relative to the manufacture of these mirrors in Japan, from which it appears that scraping is resorted to previous to polishing, great pressure being used. These researches were undertaken by $\mathrm{Mr}$. Thorp with a view to determine whether the same "magic" effect can be produced by the ordinary methods of grinding and polishing. Replicas of a Japanese mirror capable of showing the " magic" effect in a very slight degree were made in hard bronze (bell metal). One of these was ground and polished by the method used for glass, \&c., considerable pressure being used in the polishing. The result was a decided improvement on the original. The second replica was now ground and polished in a similar manner, but under conditions which prevented flexure during the processes. The result was a plane mirror, without the "magic" properties. As straining the first mirror had been noticed to give enhanced effects, the plane mirror was now subjected to uniform pressure from the back, when the design was seen to start out in a very decided manner, being much brighter than the rest of the surface. On the mirror 
being subjected to a partial vacuum, again from the back, portions of the design were seen to be darker than the surrounding surface, but bordered with a light fringe. It appears now to be thoroughly established that the cause of the "magic" effect in Japanese mirrors is due to the unequal resistance to flexure during the polishing process.

\section{PARIS.}

Academy of Sciences, February I6.-M. Albert Gaudry in the chair.- The President announced to the Academy the death of Sir George Gabriel Stokes, foreign associate.A law relating to the electromotive forces of batteries based on the reciprocal action of saline solutions and soluble electrolytes, by M. Berthelot.-A direct and simple calculation of the velocity of propagation of a wave front in a medium having complicated equations of motion, by $M$. J . Eoussinesq.-On the radiation of polonium and radium, by $M$. Henri Becquerel. In a previous paper the author has shown that the $a$-rays of Rutherford, which are probably identical with the Kanalstrahlen of Goldstein, are capable of a slight deviation in a strong magnetic field. The present paper is devoted to a proof of the existence of a corresponding property in the radiation from polonium. Owing to the very slight photographic action of the specimen of polonium under examination, the action had to be prolonged for twenty hours. The same apparatus was used for comparative experiments with radium. The two photographic proofs, the one with radium and the other with polonium, appeared to be superposable, thus proving the absolute identity under the conditions of the experiment of the $a$-radium rays and the polonium rays. In neither case was there any trace of dispersion analogous to that observed with the kathode rays.-On some new syntheses effected by means of molecules containing the methylene group associated with one or two negative radicles. The action of epichlorhydrin on the sodium derivatives of acetone-dicarboxylic esters, by MM. A. Haller and F. March. The sodium derivative of acetone-dicarboxylic acid condenses readily with epichlorhydrin, giving a keto-lactone, the properties of which, with those of its semicarbazone, are described.-Approximate algebraic expressions for transcendental, logarithmic and exponential functions, by M. J. A. Normand. A series of formulæ is developed permitting of the rapid calculation of the numerical value of logarithms. Numerous examples showing the degree of approximation are appended.- Remarks by. $M$. Considere on a memoir on the resistance of armed mortars.-M. René Benoit was elected a correspondant in the section of physics in succession to the late Prof. Rowland.-The eruption of Mont Pelée in January, 1903, by M. A. Lacroix.-Perturbations independent of the eccentricity, by M. Jean Mascart.-Researches on electrolytic valves, by M. Albert Nodon. The term electrolytic valve is applied to an electrolytic cell for the conversion of an alternating current into a unidirectional current. Metals having a low atomic weight, such as magnesium or aluminium, are the best for this purpose, and a solution of ammonium phosphate forms the best electrolyte. The electrostatic capacity of these cells is considerable, about I farad per square centimetre of surface of aluminium, the thickness of the dielectric which forms the condenser being of the order $1 \mathrm{I}^{-8}$, or of molecular order. Such a cell may be successfully applied to the rectification of telephone currents, and can be used for their measurement.-On the induced radio-activity produced by salts of actinium, by M. A. Debierne. It is known that the compounds of radium possess the property of rendering bodies placed in their vicinity temporarily radio-active. Actinium salts possess the same property, the effects produced presenting the same general characters as with radium. There are, however, differences distinguishing the action of the two elements.The conditions of estimation of manganese in acid solution by persulphates, by M. H. Baubigny. A series of determinations is given, showing the effect of the nature of the acid, its quantity and the amount of persulphate used.--The heats of formation of some sulphur and nitrogen compounds, by M. Marcel Delépine.-The action of hydrogen upon silver sulphide in the presence of the sulphides of antimony and arsenic, by M. H. Pélabon.-The action of phosphoric acid upon erythritol, by M. P. Carré. Phosphoric acid acts upon erythritol firstly as a dehydrating agent, and then forms a mono-ester of erythrane. A portion of the latter is converted into a di-ester.- The preparation of some combinations of $\alpha$-methyl- $\alpha$-isopropyl-adipic acid, by M. C. Martine.-On the temperature of calefaction, and on its use in alcohol determinations, by M. Bordier. The term point of calefaction is applied to the temperature at which contact ensues between a hot plate and a drop of liquid in the spheroidal state. In the case of mixtures of alcohol and water this temperature is a function of the composition, and the use of this method is suggested as a means of determining the amount of alcohol in solution. It has the advantage of requiring only a very small quantity of liquid.-On the pathogenic action of the rays emitted by radium on different tissues and organisms, by M. J. Danysz. The action is most intense on the skin, the action being relatively slight upon the underlying tissue and attached muscle. The nervous system is especially sensitive to the action of the rays. The larvæ of insects exposed to the rays were paralysed in twenty-four hours and died two days later.-The mechanism of the action of secretin on the pancreatic secretion, by M. C. Fleig. The experiments given tend to show that secretin acts directly upon the pancreas, either acting directly upon the pancreatic cell or on the excito-secretory elements. Secretin, contrary to the views of Popielski, offers a good example of special chemical substances which, by their diffusion in the blood current, establish relations between certain determined organs.-The action of the fundamental vibrations of the vowels on the ear in a pathological state, by M. Marage.-On the implantation of dead bone in contact with living bone, by MM. V. Cornil and P. Coudray. Dead bone remains very nearly in the condition in which it was implanted, embedded in a fibrous capsule. It behaves almost like a foreign body, its resorption, even at the end of six months, being insignificant.-On Châtaignier's disease, caused by Mycelophagus Castaneae, by M. L. Mangin.-A new genus of Chytridiaceæ, by M. P. A. Dangeard.-Phenomena of transportation in the eastern Mediterranean, by M. L. cayeux. - The absorption of ammonia by sea-water, by M. J. Thoulet.

New South Wales.

Royal Society, December 2, 1902.-Prof. Warren, president, in the chair.- On the occurrence of an important geological fault at Kurrajong Heights, Blue Mountains, by Prof. T. W. Edgeworth David, F.R.S. Traced in a southerly direction across the Grose Valley to Glenbrook Railway Station, the fault dies out, passing into a gentle westerly fold, which does not appear to have been accompanied by shearing. To the east is the well-known steep easterly monocline. Traced northerly, the monocline crosses Grose Valley and forms the eastern slope of Kurrajong Heights. The monocline at the Kurrajong is bounded westwards by an abrupt fault, whereas at Glenbrook the line of disturbance takes the form of a gentle fold facing the west. The fault plane, though somewhat eroded, still forms a steep and very conspicuous escarpment. The effect of this fault in displacing the Coal-measures on either side of it will obviously claim the serious attention of those who, in the future, have charge of coal mines in that portion of our coalfields. Investigations in regard to the comparative strength and elasticity of Portland cement, mortar and concrete, when reinforced with steel rods and when not reinforced, by Prof. W. H. Warren. The paper describes experiments on various mortars and concrete in tension and compression, also when subjected to bending stresses. The extensions of the specimens subjected to direct tension when reinforced with steel rods were considerably less than occurred in similar specimens not reinforced; the stress-strain diagrams plotted from the observations taken were all convex to the stress axis, but the curve was much flatter for the reinforced specimens. The transverse tests consisted of experiments with beams reinforced on the tension side with steel rods, compared with similar beams not reinforced. In alt cases the reinforced beams were from $5^{\frac{1}{2}}$ to so times stronger than the plain beam, and the deflections of the beams before fracture were enormously greater in the reinforced beams. -The fallacy of assuming that a wet year in England wiil be followed by a wet year in Australia, by H. C. Rusesil, 
F.R.S. It is a widespread idea that if abundant rain falls in England there will be an abundant rainfall in Australia in the following year. By means of a diagram showing the rainfall in England and in Sydney for a number of years in succession, it is shown that, as a matter of fact, this seldom occurs.-On the presence of platinum and iridium metals in meteorites, by Prof. Liversidge, F.R.S. The author described the occurrence of gold in meteorites in certain cases, the gold is accompanied by one or more of the platinum and iridium metals. The Boogaldi meteorite contains both gold and one or more of the platinum metals these metals do not appear to be uniformly diffused through the meteorite, for some parts apparently contain a much larger proportion than others. The amount of the platinum metals in the Boogaldi meteorite is comparatively large, being at the rate of several ounces per ton.--Is Eucalyptus variable? by Mr. J. H. Maiden. The author takes the following characters seriatim, and shows that they all vary :--Habit, bark, timber, exudations, petiole, leaf(a) suckers, (b) cotyledon leaves, (c) venation, (d) young stems, $(e)$ essential oil, $(f)$ stomata-galls, inflorescence, anthers, pollen-grains, calyx, fruit.

\section{DIARY OF SOCIETIES.}

\section{THURSDAY, FEBRUARY 26 .}

Royal Society, at 4.30--Bakerian Lecture: Solid Solution and Chemical Transformation in the Bronzes : C. T. Heycock, F.R.S., and F. H. Neville, F.R.S.

Royal Institution, at 5.-Insect Contrivances: Prof. L. C. Miall, F.R.S.

Society of ARts, at $4 \cdot 30 .-$ Gleanings from the Indian Census: J. A Baines.

Institution of Electrical EngineERs, at 8.-The Nernst Lamp: J. Stöttner.-And, if time permit, Distribution Losses in Electric Supply Systems: A. D. Constable and E. Fawsstt. - A Study of the grams : M. B. Field.

FRIDAY, FEBRUARY 27

Royal Institution, at 9.-Perfumes: Natural and Artificial : Dr. A. Liebmann.

Physical Society, at 5.-On the Measurement of Small Capacities and Inductances: Prof. Fleming and Mr. Clinton.-On the Interpretation of Milne Seismograms : Dr. Farr.-On the thickness of the Liquid Film formed by Condensation at the Surface of a Solid: Dr. Parks.

Institution of Civil Engineers, at 8.-The Relative Advantages of Single Screws, Twin Screws, and Triple Screws, for Marine Propulsion: E. Falk.

SATURDAY, FEBRUARY 28.

Royal Institution, at 3.-Light: Its Origin and Nature: Lord Rayleigh.

Essex Field Club (Essex Museum of Natural History, Stratford), a 6.30.- The British Vespidæ and their Vespiaries : Edward Connold.

\section{MONDAY, MARCH 2.}

Society of ARTs, at 8.-Hertzian Wave Telegraphy in Theory and Practice: Prof. J. A. Fleming, F.R.S.

Society of Chemical Industry, at 8.-The Need of Duty-Free Alcohol for Industrial Purposes: Thomas Tyrer.

\section{$T U E S D A Y, M_{A R C H}$.}

Royal Institution, at $5 .-$ Recent Advances in Photographic Science : Sir William Abney, K.C.B.

Institution of CIVIL ENGINeERs, at 8.-Paper to be further discussed. -Mechanical Handling of Material: G. F. Zimmer. - Succeeding Papers. -Recent Irrigation in the Punjab: S. Preston.-The Irrigation Weir across the Bhadar River, Kathiawar: J. J. B. Benson.

Zoological Society, at 8.30.-Observations and Experiments on Japanese Long-Tailed Fowls: J.T. T. Cunningham.-On the Land Operculate Mollusca collected during the "Skeat Expedition" to the Malay Peninsula: E. R. Sykes.-The Significance of the Callosities on the Limbs of the Equida: : R. Lydekker.

Society of ARts, at 4.30.-The Uganda of To-day: Herbert Samuel.

\section{WEDNESDAY, MARCH 4}

Society of ARTs, at 8.-Education in Holland: J. C. Medd.

Entomological Society, at 8. - The Aculeate Hymenoptera of Barrack pore, Bengal: G. A. James Rothney.-Notes on the Nests of Bees of the Genus Trigona: Chatles Owen Waterhouse.-On the Aganiidæ in the British Museum, with Descriptions of some New Species: Colone C. Swinhoe.

\section{THURSDAY, MARCH 5}

Royal Socrety, at 4.30.-Probable Papers:-The Resistance of the Ions and the Mechanical Friction of the Solvent: Prof. F. Koblrausch For. Mem. R.S. - The Electrical Conductivity of Solutions at the Freezing Point of Waier: W. C. D. Whetham, F.R.S.-A Note on Form of Magnetic Detector for Hertzian Waves adapted for Quantitative NO, I 739, VOL. 67$]$
Work : Prof. J. A. Fleming, F.R.S.-On the Laws governing Electric Discharges in Gases at Low Pressures: W. R. Carr.-The Differential Invariants of a Surface, and their Geometric Significance: Prof. A. R. Forsyth, F.R.S.

Royal Institurion, at 5,-Insect Contrivances : Prof, L. C. Miall,F.R.S. Society of Public Analysts, at 8.

Chemical Society, at 8.-The Mechanism of the Reduction of Potassium Bichromate by Sulphurous Acid : H. Bassett.-The Constitution of Pilocarpine. Part IV.: H A. D. Jowett.-Preparation and Properties of $x: 4$ (or $x: 5$ )-Dimethyl Glyoxaline and $x: 3$-Dimethyl Pyrazole : $H$. A. D. Jowett and C. E Potter-Some Analyses of "Reh"" or the Alkaline Salts in Indian Usar Land: E. G. Hill.-Experiments on the Synthesis of Camphoric Acid. Part III. Synthesis of Isolauronolic Acid: W. H. Perkin In and J. F. Thorpe-Camphor- $\beta$-thiol: T. M. Lowry and Perkin, Jun., and J. F. Thorpe.-Camphor- $\beta$-thiol: T. M. Lowry and G. C. Donington.-Isomeric Change of Dibenzanilide in to Benzoylorthoamino- and Benzoylpara-amino- Benzophenone : F. D. Chattaway.-The ture Coefficient : J. C. Cain and F. Nicoll.

LinNeAN Society, at 8.-On some Points in the Visceral Anatomy of the Characinida: 'W. S. Rowntree.-On the Anatomy of the Pig.footed Bandicoot Chaeropus castanotis: F. G. Parsons. - Further Notes on Lemurs: Dr. Elliot Smith.

Röntgen Society, at 8.30.-Spark Phenomena: F. H. Glew.

FRIDAY, MARCH 6.

Roval Institution, at 9.- Studies in Experimental Phonetics; Prof. J. G. McKendrick, F.R.S.

\section{SATURDAY, MARCH 6 .}

Roval Institution, at 3.-Light: Its Origin and Nature: Lord Rayleigh.

\section{CONTENTS}

PAGE

The Living Substance-A Theory . . . . . . . . 385

Science and Practice. By R. T. G. . . . . . . 386

The Infinities of Mathematics. By G. B. M. . . 387

Practical Physiology . . . . . . . . 388

Our Book Shelf :-

Smith: "Studies in the Cartesian Philosophy." -

G. S. B. - . Pressive Reduktion der Variabilität und ihre Beziehungen zum Aussterben und zur Entstehung der Arten."-J. A. T.

Watson: "Steel Ships: their Construction and Maintenance. A Manual for Shipbuilders, Ship Superintendents, Students and Marine Engineers"

Porro: "Elementi di Geografia Fisica, Fisica Terrestre e Meteorologia, ad uso delle Scuole Classiche, Tecniche, Normali et Agrarie."H. R. M. . . . . . . . 390

Letters to the Editor:-

Cambridge Mathematics.-Prof. John Perry, F.R.S. ${ }^{2}$ adio-activity of Ordinary Materials.-Prof. J. J. Thomson, F.R.S. Fall of Coloured Dust on February 22-23. - Wm

Marriott .

Chapman's Zebra.-Prof. T. D. A. Cockerell 391 American Magical Ceremonies. (Illustrated.) By A. C. $\mathrm{H}$.

The Fata Morgana of the Straits of Messina. (Illustrated.) By G. H. B. . . . . . 393 Indian Rainfall. By Dr. William J. S. Lockyer . 394 The Afforestation of the Black Country. By Prof. W. Schlich, F.R.S. . . . . . . . . 395

Notes ... . . . . . . . . . 396

Our Astronomical Column :-

Photographs of the North Polar Region . . . . . 400

A Device for Obtaining Good Seeing . . . . . . 400

Proper Motion of the Sun Compared with Stellar

Velocities . . . . . . . . . . 400

Discovery of Ancient Astronomical Records . . . . 400 Animal Thermostat. By Lord Kelvin, G.C.V.O. 401 Bacterial Treatment of Crude Sewage. By Prof.

Frank Clowes, F.R.S. . . . . . . . . . . 402

Silica Glass . . . . . . . . . 403

Sir William Hooker's Scientific Work . . . 404

University and Educational Intelligence . . . . . 404

Scientific Serial . . . . . . . . . 405

Societies and Academies

Diary of Societies ................. 408 